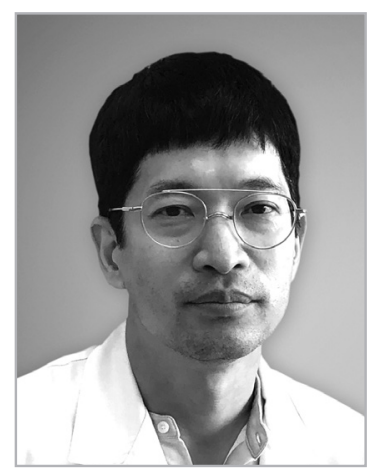

\title{
환경과 폐질환
}

\section{김 우 진}

강원대학교 의과대학 내과학교실

\section{Environment and lung diseases}

Woo Jin Kim, MD

Department of Internal Medicine, Kangwon National University School of Medicine, Chuncheon, Korea

Genetic and environmental risk factors influence the development of respiratory diseases. While cigarette smoking is a personal risk factor, ambient air pollution and chemicals such as asbestos are major environmental risk factors for respiratory diseases. In addition, the growth of children's lung is also sensitively affected by environmental exposure to pollutants and heavy metals. Many studies have found that certain populations including children, elderly and residents near chemical factories are more susceptible to environmental lung diseases, which indicate the importance and benefits of strategic planning at the national level. Although genetic risk factors may be hard to control, many of the environmental risk factors can be prevented and managed by correct policy-making. Therefore, in-depth researches should be continued, and careful considerations should be given to policy-making in efforts to lower environmental risk factors and make a better environment for the future generation. Environmental exposure leads to epigenetic changes in airway and lung tissues as well as blood cells. Although not yet completely understood, the mechanism involved in such changes can act as biomarkers or therapeutic targets for the diagnosis and treatment of environmental lung diseases.

Key Words: Environmental exposure; Lung diseases; Air pollutants; Heavy metals

\section{서론}

환경성 폐질환은 크게 보면 유전적인 요인에 의한 폐질환 을 제외한 대부분이 포함될 것이나, 환경보건법에 의한 환경 성 질환에는 대기오염, 화학물질, 석면 노출에 의한 질환이 해당한다. 환경보건법에는 언급되지 않지만, 흡연은 환경요

Received: February 18, 2021 Accepted: March 11, 2021

Corresponding author: Woo Jin Kim

E-mail: pulmo2@kangwon.ac.kr

\section{(C) Korean Medical Association}

This is an Open Access article distributed under the terms of the Creative Commons Attribution Non-Commercial License (http://creativecommons. org/licenses/by-nc/3.0) which permits unrestricted non-commercial use, distribution, and reproduction in any medium, provided the original work is properly cited.
인 중에 폐질환에 영향을 미치는 것으로 가장 잘 알려져 있 다[1]. 흡연은 폐암과 만성폐쇄성폐질환의 가장 중요한 위험 요인이고, 그 외에도 많은 질환을 일으킬 수 있기에 금연을 통해 질환의 위험을 줄이는 동시에 삶의 질 또한 높일 수 있 다. 흡연은 개인의 선택이지만 여러 사회· 문화적인 요인들 이 개인의 선택에 영향을 미칠 수 있어 흡연율을 낮추기 위 해서는 정책적인 접근이 필요하다. 미세먼지나 중금속 노출 등과 같은 다른 환경요인의 경우, 개인의 의도와 무관하게 노출이 될 수 있고, 특히 취약계층에서 더 많이 영향을 받는 다는 점에서 환경에 의한 건강영향을 파악하고 국가적 차원 에서 대책을 세우는 것이 필요하다. 취약계층뿐만 아니라 전 국적으로 단기적 및 장기적 영향을 미칠 수 있는 대기오염과 화학물질에 대해서는 더 많은 관심을 필요로 한다. 


\section{대기오염과 폐질환}

폐질환을 일으키는 대표적인 환경요인으로 미세먼지가 가장 잘 알려져 있다[2]. 우리나라의 미세먼지 연평균 농 도는 최근 수년간 $25 \mu \mathrm{g} / \mathrm{m}^{3}$ 내외를 유지하다가 2020년 $19 \mu \mathrm{g} / \mathrm{m}^{3}$ 로 개선되었다. 그러나, 아직 우리나라 기준인 연 평균 $15 \mu \mathrm{g} / \mathrm{m}^{3}$ 와 세계보건기구 기준인 $10 \mu \mathrm{g} / \mathrm{m}^{3}$ 을 충족하 기 위해서는 개선의 여지가 크다. 미세먼지 수준이 개선될 경우 건강에 좋은 영향이 있다는 것은 많은 연구들을 통해 서 보고되었다[3]. 특히 미세먼지 연평균 농도가 감소함에 따라 아이들의 폐성장이 증가하였다는 것이 미국에서 분석 한 연구에서 보고되었고, 이 연구결과를 여러 나라에서 미세 먼지 저감정책의 과학적 근거로 인용하고 있다[4]. 최근 연 구는 미세먼지의 농도를 전반적으로 줄이는 것도 중요하지 만, 배출원에 따라서 미세먼지의 건강영향이 다를 수 있으므 로 미세먼지 성분 중에서 어떤 성분이 특히 더 건강에 악영 향을 주는지와 미세먼지의 산화잠재력의 차이에 따른 건강 영향은 어떤 지에 대한 연구들이 이루어지고 있다. 이러한 연구결과들이 미세먼지 저감에 우선 순위를 정할 때 참고될 것으로 기대한다.

한편, 오존의 경우는 미세먼지 농도가 낮은 북미 지역에서 도 증가하는 추세이다[5]. 최근까지의 연구결과에서 오존이 기여하는 사망률과 질병에 대한 영향이 미세먼지보다 높진 않지만, 미세먼지 농도는 감소하는 반면 대기중의 오존 연 평균 농도는 증가 추세인 만큼 앞으로 관심을 가져야 한다.

\section{화학물질과 폐질환}

중금속과 다환방향족탄화수소(polycyclic aromatic hydrocarbon) 등이 호흡기 건강에 영향을 미치고, 폐질환을 일으킬 수 있다고 알려져 있다. 이들은 미세먼지의 구성성분 이기도 하고, 다른 경로로 체내에 흡수되기도 한다. 중금속 농도는 국민건강영양조사나 국민환경보건 기초조사를 통해 국민들의 체내 중금속 수치를 측정하여 기초자료로 삼고있 는데, 일부 중금속은 폐질환 또는 폐기능과의 연관성이 발표
되었기에 폐건강을 위해서라도 주의를 기울여야 하겠다. 우 리나라에서는 가습기살균제로 인한 폐질환이 발생하여 사망 을 하거나 심각한 후유증을 남기기도 하였다. 과거의 노출로 인해 발생한 질환이지만 현재까지 많은 환자들이 고통받고 있는 것이 사실이다. 화학물질의 폐독성이 적절하게 검증되 지않고 상품으로 판매되어 일어난 경우로, 이러한 비극이 반 복되지 않도록 철저한 관리가 필요하겠다. 지역적으로 산업 단지나 공장 근처에서 거주하는 경우 공장에서 일을 하지 않 더라도 유해물질에 노출될 수 있다[6]. 이런 경우는 상대적 으로 저농도로 노출될 가능성이 높지만, 지속적인 노출로 인 해 만성질환으로 나타날 수 있음에도 불구하고 명백한 인과 관계를 증명하기는 어려울 수 있다.

\section{환경성 폐질환의 기전}

악성종양의 경우 체세포 돌연변이가 주된 발병기전으로, 돌연변이가 생기고 암이 발병하는데 있어서 환경적인 요인 이 관여하는 것으로 알려져 있다. 대개의 흔한 질병에서 환 경에 의한 생물학적인 영향은 유전자와 발현과 단백질의 작 용을 통해 이루어지며, 후성유전체는 유전자 발현을 조절하 는 것으로 알려져 있다. 환경 노출에 의해 후성유전체가 어 떠한 영향을 받는지에 대해 많은 연구들이 보고되고 있고, 호흡기질환들도 후성유전체 변화를 동반하는 것으로 알려져 있어 후성유전체를 매개로 한 기전이 환경성 폐질환에서 매 우 중요하다[7]. 자세한 기전이 밝혀지면 환경노출을 정확하 게 평가하는 도구가 개발될 수 있고, 환경성 폐질환의 치료 제로도 개발될 수 있을 것으로 기대한다.

\section{결론}

폐는 호흡을 통해 환경에 직접 노출되는 장기이므로 환경 에 의해 크게 영향을 받고, 또한 여러 환경성 질환에 취약하 다. 환경변화가 우리의 건강에 큰 변화를 일으킬 수 있는 만 큼 개인의 노력뿐만 아니라 국가와 사회가 좋은 환경에서 건 
강한 삶을 영위할 수 있도록 과학적인 연구결과들을 바탕으 로 한 정책들을 펴나가야 한다.

찾아보기말: 환경노출; 폐질환; 대기오염; 중금속

\section{ORCID}

Woo Jin Kim, https://orcid.org/0000-0003-2927-370X

\section{Conflict of Interest}

No potential conflict of interest relevant to this article was reported.

\section{References}

1.Park YS, Park S, Lee $\mathrm{CH}$. The attributable risk of smoking on all-cause mortality in Korean: a study using KNHANES IV-VI
(2007-2015) with mortality data. Tuberc Respir Dis (Seoul) 2020;83:268-275.

2.Kyung SY, Jeong SH. Particulate-matter related respiratory diseases. Tuberc Respir Dis (Seoul) 2020;83:116-121.

3.Schraufnagel DE, Balmes JR, De Matteis S, Hoffman B, Kim WJ, Perez-Padilla R, Rice M, Sood A, Vanker A, Wuebbles DJ. Health benefits of air pollution reduction. Ann Am Thorac Soc 2019;16:1478-1487.

4.Gauderman WJ, Urman R, Avol E, Berhane K, McConnell R, Rappaport E, Chang R, Lurmann F, Gilliland F. Association of improved air quality with lung development in children. N Engl J Med 2015;372:905-913.

5. Kim SY, Kim E, Kim WJ. Health effects of ozone on respiratory diseases. Tuberc Respir Dis (Seoul) 2020;83(Supple 1):S6S11.

6. Han Y, Heo Y, Hong Y, Kwon SO, Kim WJ. Correlation between physical activity and lung function in dusty areas: results from the chronic obstructive pulmonary disease in dusty areas (CODA) Cohort. Tuberc Respir Dis (Seoul) 2019;82:311-318.

7. Bae DJ, Jun JA, Chang HS, Park JS, Park CS. Epigenetic changes in asthma: role of DNA CpG methylation. Tuberc Respir Dis (Seoul) 2020;83:1-13. 